\title{
Catalytic Effect of Silver on Bioleaching of Arsenopyrite
}

\author{
Fang Fang, Hong Zhong, Fangming Jiang, and Xuehui Zhan
}

\begin{abstract}
A study of the effect of different variables $\left(\mathrm{Ag}^{+}\right.$ concentration, pulp density, $\mathrm{pH}$, inoculation, $\mathrm{Fe}^{3+}$ concentration) on the silver-catalyzed bioleaching of arsenopyrite by Acidithiobacillus ferrooxidans NSJ209 strains has been carried out in shake flasks. Results showed: $\mathrm{Ag}^{+}$has catalytic effect on arsenopyrite bioleaching. Especially, with the presence of $\mathrm{Fe}^{3+}$, the catalytic effect is even better. When the $\mathrm{Ag}^{+}$concentration is $2 \mathrm{mg} / \mathrm{L}$; the pulp density is $2 \%$; the $\mathbf{p H}$ is 2.0 ; after leaching for 16 days, the arsenic leaching rate is improved about $23.14 \%$ compared with leaching rate when $\mathrm{Ag}^{+}$is not added. However, high concentrations of $\mathrm{Ag}^{+}$will affect the bacterial growth and activity, resulting in a decline of the leaching rate.
\end{abstract}

$\begin{array}{ccc}\text { Index Terms-Acidithiobacillus } & \begin{array}{r}\text { ferrooxidans, } \\ \text { arsenic-containing gold }\end{array} \text { concentrate, } & \text { silver-catalyzed, }\end{array}$
bioleaching, arsenopyrite.

\section{INTRODUCTION}

In recent years, the bacterial pre-oxidation technique has become increasingly competitive because of advantages such as low cost, low energy consumption, environmentalprotection, and ease of operation. However, this technique has certain problems at the current stage. The low leaching speed and long leaching cycle are the main factors that prevent the industrialization of this technique [1]-[4]. Physical, chemical, and biological methods can be applied to strength the bioleaching process of sulphide minerals, so as to improve the leaching speed [5]-[7]. Among these methods, bioleaching with $\mathrm{Ag}^{+}$addition is the most explored and the most effective strengthening method. For example, the study conducted by Zhang et al. [8] indicated that $\mathrm{Ag}^{+}$had a significant catalytic effect on the bioleaching and chemical leaching of realgar $\left(\mathrm{As}_{2} \mathrm{~S}_{2}\right)$. Hu et al. [9] added 0.32g of silver ions, 4 grams of $\mathrm{Ag}_{2} \mathrm{~S}$, and 20 grams of $\mathrm{Ag}-\mathrm{C}$ to each kilogram of chalcopyrite. After bacterial leaching in a shake flask for 20 days, the copper leaching rates were increased from $25 \%$ (without catalyzer) to $75 \%, 65 \%$, and $67 \%$, respectively. Muñoz et al. [10]-[12] investigated the catalytic effect of $\mathrm{Ag}^{+}$on the shake flask leaching, stirred reactor leaching, and column reactors leaching of the low-grade copper ore. They claimed that adding a small amount of silver ions could improve the

Manuscript received January 10, 2014; revised April 20, 2014. This work was financially supported by National Natural Science Foundation of China (No.51104024 and 51374043) and Hunan Provincial Natural Science Foundation of China (No.10JJ6019).

Fang Fang and Xuehui Zhan are with the College of Chemistry and Biological Engineering, Changsha University of Science and Technology, Changsha, China (e-mail: lgdx08@sina.com).

Fang Fang and Hong Zhong are with School of Chemistry and Chemical Engineering, Central South University, Changsha, China. They are also in the Key Laboratory of Resources Chemical of Nonferrous Metals, Ministry of Education,Central South University, Changsha, China.

Fangming Jiang is with the Hunan Exit-Entry Inspection and Quarantione Bureau, Changsha, China. copper leaching speed significantly; however, adding excessive amount of silver ions would inhibit the bioleaching of copper. When leaching in a shake flask, adding $294.1 \mathrm{~g}$ of $\mathrm{Ag}^{+} / \mathrm{kgCu} \mathrm{as}$ catalyzer and leaching for 14 days, the copper leaching rate increased about $97 \%$. Compared with the $\mathrm{Ag}^{+}$ addition-free leaching rate (18\%), adding $\mathrm{Ag}^{+}$increased the copper leaching rate by about $79 \%$. Miller et al. [13] and Wang et al. [14] investigated the catalytic mechanism of $\mathrm{Ag}^{+}$ on chopper bioleaching. They believed that $\mathrm{Ag}^{+}$catalyzed copper bioleaching through lattice substitution to form a layer of porous $\mathrm{Ag}_{2} \mathrm{~S}$ membrane on the chalcopyrite surface. This layer of $\mathrm{Ag}_{2} \mathrm{~S}$ membrane was then quickly oxidized by $\mathrm{Fe}^{3+}$, so as to greatly improve the speed of chalcopyrite bioleaching. Without $\mathrm{Ag}^{+}$addition, a layer of dense elemental sulfur membrane was generated on the surface of the chalcopyrite, which seriously impeded the continuation of the mineral leaching. Therefore, adding $\mathrm{Ag}^{+}$to strengthen the bioleaching process of sulphide minerals is an effective way to improve the speed of sulphide leaching and to shorten the leaching cycle. However, few studies have reported adding $\mathrm{Ag}^{+}$to the arsenic-containing gold concentrates to enhance its bioleaching [15]. To bridge this research gap, this study focused on the main gold-bearing mineral, arsenopyrite, investigated the catalytic effects of $\mathrm{Ag}^{+}$on arsenopyrite bioleaching. These studies are theoretically important and have high application value for shortening the bioleaching cycle and promoting the industrialization of the bioleaching of arsenic-containing gold concentrates.

\section{PROCEDURE FOR PAPER SUBMISSION}

\section{A. Bacteria and Medium}

Acidithiobacillus ferrooxidans specimens were obtained by separating and purifying the bacteria from an acid mine drainage of chinese high-arsenic gold ore and subsequently mutating and domesticating the bacteria. The isolated bacteria were designated as NSJ209. The following is the optimum culturing conditions for NSJ209: $\mathrm{pH}, 2.0$; temperature, $30^{\circ} \mathrm{C}$; and rotating speed, $180 \mathrm{r} / \mathrm{min}$. The culture medium is $9 \mathrm{~K}$ medium, which contained the following components $(\mathrm{g} / \mathrm{L})$ : $\mathrm{FeSO}_{4} \cdot 7 \mathrm{H}_{2} \mathrm{O}$ (44.7), $\left(\mathrm{NH}_{4}\right)_{2} \mathrm{SO}_{4}(3.0), \mathrm{KCl}(0.1), \mathrm{K}_{2} \mathrm{HPO}_{4}$ (0.50), $\mathrm{MgSO}_{4} \cdot 7 \mathrm{H}_{2} \mathrm{O}(0.50), \mathrm{Ca}\left(\mathrm{NO}_{3}\right)_{2}(0.01) .6$ mol. $\mathrm{L}^{-1}$ $\mathrm{H}_{2} \mathrm{SO}_{4}$ was used to adjust the $\mathrm{pH}$ of the medium to 2.0. All chemical reagents were used of analytical grade.

\section{B. Mineral Specimens for Experiment}

The test arsenopyrite was purchased from Changsha Mineral Resources Supervise Test Centre of Territory Resource Department. The samples were hand-selected, soaked in dilute hydrochloric acid, cleaned by deionized water, finely grinded by a porcelain ball mill, removed 
magnetic minerals by magnetic separator, finely grinded into particles with sizes less than $74 \mu \mathrm{m}$ by a porcelain ball mill, and then placed in a desiccator for future use.The major elements found in the arsenopyrite were $\mathrm{Fe}, \mathrm{S}$ and $\mathrm{As}$, accounting for $32.46 \%, 18.30 \%$ and $42.56 \%$, respectively.

\section{Experimental Means}

Arsenopyrite powder was accurately weighed and added to a $250 \mathrm{~mL}$ shake flask. $9 \mathrm{~K}$ ironless medium $(50 \mathrm{~mL})$ was added to the shake flask to pre-leach the powder for $24 \mathrm{~h}$. Bacteria $(10 \mathrm{~mL})$ in the logarithmic growth phase were inoculated to the mixture (abiotic control tests received $10 \mathrm{~mL}$ of $2 \mathrm{~g} / \mathrm{L}$ thymol in methanol instead of the inoculum ), and additional medium was added until a constant volume of $100 \mathrm{~mL}$ was reached. $6 \mathrm{M} \mathrm{H}_{2} \mathrm{SO}_{4}$ was used to adjust the $\mathrm{pH}$ of the pulp to 2.0 , arsenic was leached by vibration in an air bath constant-temperature shaking incubator where the temperature was $30^{\circ} \mathrm{C}$, and the rotating speed was set to $180 \mathrm{r} / \mathrm{min}$. The amount of water lost by evaporation during leaching was replaced with the same amount of distilled water and the liquid consumed by collecting samples was replaced with $9 \mathrm{~K}$ ironless medium ( $\mathrm{pH} 2.0$ ). The oxidation-reduction potential(ORP) and gross arsenic content (equivalent to the sum of $\mathrm{As}(\mathrm{III})$ and $\mathrm{As}(\mathrm{V})$ )in the leached residues were measured every other $24 \mathrm{~h}$, and the arsenic leaching rate was calculated.

\section{Analytical Method}

To measure bacterial density, a blood cell counting chamber was used to directly count the bacteria using a microscope. A PHSJ-4A portable acidometer produced by Shanghai INESA Scientific Instrument Co., Ltd. was used to measure $\mathrm{pH}$. The new silver salt spectrophotometry method was used to measure the gross arsenic content. $\mathrm{Fe}^{2+}$ concentration was determined with titration by potassium dichromate (refer to GB/T 6730.8), The oxidation-reduction potential $E_{h}$ was calculated using the formula $E_{h}=E_{m}+240$ $\mathrm{mV}$. ( $\mathrm{E}_{\mathrm{h}}$ is the potential relative to the standard hydrogen electrode (vs.SHE), $\mathrm{E}_{\mathrm{m}}$ is the potential value measured using the calomel electrode (reference electrode) and platinum electrode (indicator electrode). The standard potential value of saturated calomel electrode at $30{ }^{\circ} \mathrm{C}$ was $240 \mathrm{mV}$ ).

\section{RESUlTS AND DISCUSSION}

\section{A. The Effect of $\mathrm{Ag}^{+}$Concentration}

The effect of $\mathrm{Ag}^{+}$concentration on arsenopyrite bioleaching is as shown in Fig. 1. As shown in Fig. 1(a), adding an appropriate amount of $\mathrm{Ag}^{+}$to the arsenopyrite bioleaching could improve the leaching speed and the ultimate leaching rate of arsenic. However, if too much $\mathrm{Ag}^{+}$ was added, then the arsenic leaching speed would decrease. This is because $\mathrm{Ag}^{+}$has an inhibitional effect on bacteria, that is, the higher the $\mathrm{Ag}^{+}$concentration, the longer the induction period of the bacteria in the initial stage of leaching. In addition, $\mathrm{Ag}^{+}$hinders bacteria's absorption of phosphate. When excessive $\mathrm{Ag}^{+}$accumulates on the cell membrane and cell wall, it affects the intracellular material exchange, and ultimately affects the leaching speed and ultimate leaching rate of arsenic. When the concentration of $\mathrm{Ag}^{+}$was $2 \mathrm{mg} / \mathrm{L}$, arsenic had the highest leaching rate. The leaching rate reached up to $78.46 \%$ after 16 days. Compared with when $\mathrm{Ag}^{+}$was not added $(55.32 \%)$, the arsenic leaching rate was increased by about $23.14 \%$. Fig. 1(b) illustrates the impact of different $\mathrm{Ag}^{+}$concentrations on the solution ORP. As shown in Fig. 1(b), the solution ORP was decreased after adding $\mathrm{Ag}^{+}$. The more the $\mathrm{Ag}^{+}$was added, the greater the ORP was reduced, indicating that $\mathrm{Ag}^{+}$had a certain inhibitional effect on the bacterial oxidation activity.
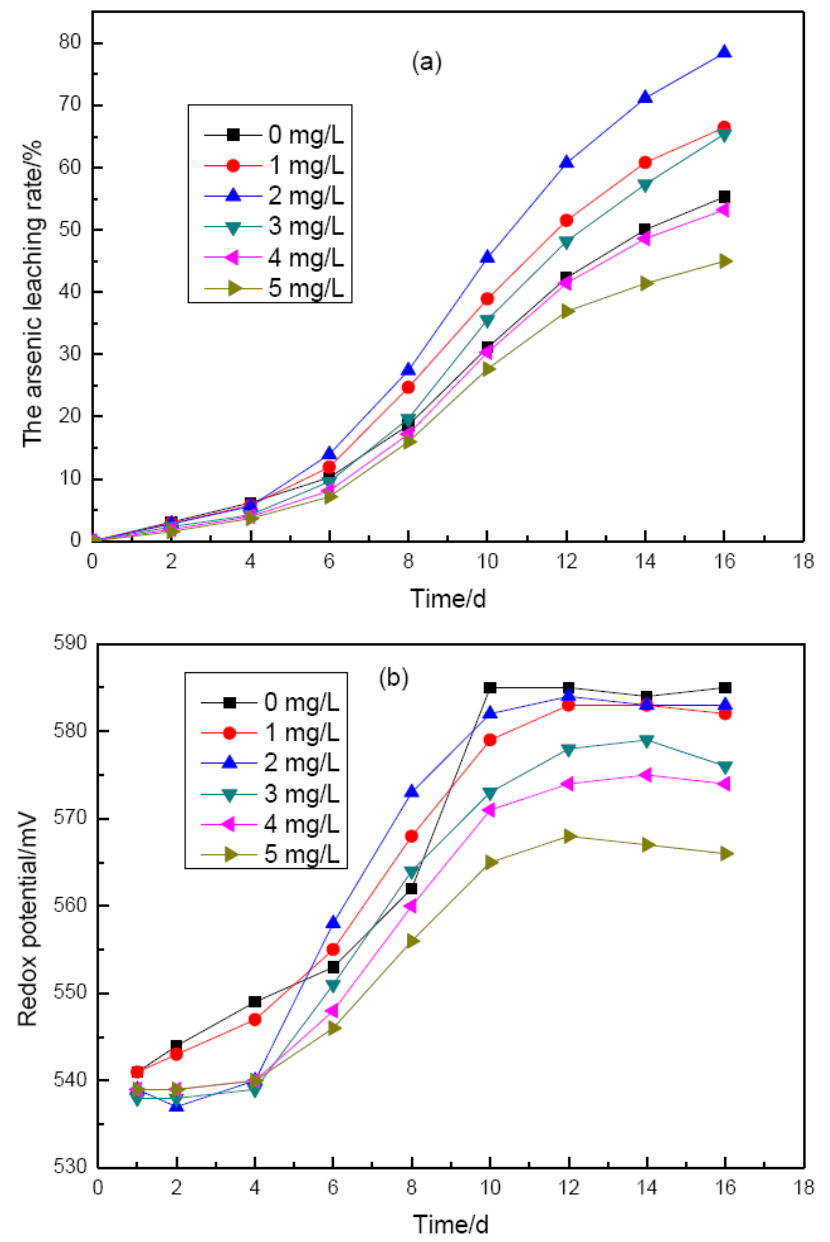

Fig. 1. Effect of silver ion concentration on the bioleaching of arsenopyrite over 16 days: the arsenic leaching rate (a) redox potential; (b) versus time respectively.

\section{B. The Effect of Pulp Density}

When the mass concentration of $\mathrm{Ag}^{+}$was $2 \mathrm{mg} / \mathrm{L}$, the effect of the pulp density on arsenopyrite bioleaching is shown in Fig. 2. As shown in Fig. 2(a), under the catalysis of $\mathrm{Ag}^{+}$, arsenopyrite had the best bioleaching effect when the pulp density was $2 \%$. The arsenic leaching rate reached $78.46 \%$ after leaching for 16 days. When the pulp density was too low $(<2 \%)$, the leaching is ineffective, because the growth of microorganisms is susceptible to nutrient deprivation, which in turn affects the growth and activity of the bioleaching bacteria. When the pulp density is too high, the high pulp density generates high shear effect and high concentrations of toxic and hazardous substances (especially As (III) and As (V)) and transmission barriers for oxygen and carbon dioxide, which are unfavorable for to the growth and reproduction of the leaching bacteria, resulting in the decline of leaching speed. As shown in Fig. 2(b), in leaching systems with 
different pulp densities, the changes of ORP showed the same trend. However, when the pulp density was $2 \%$, ORP reached the maximum of $583 \mathrm{mV}$ (SCE). When the pulp density was set as $1 \%, 3 \%, 4 \%$ and $5 \%$, the corresponding highest ORP were $580 \mathrm{mV}, 575 \mathrm{mV}, 562 \mathrm{mV}$ and $558 \mathrm{mV}$.
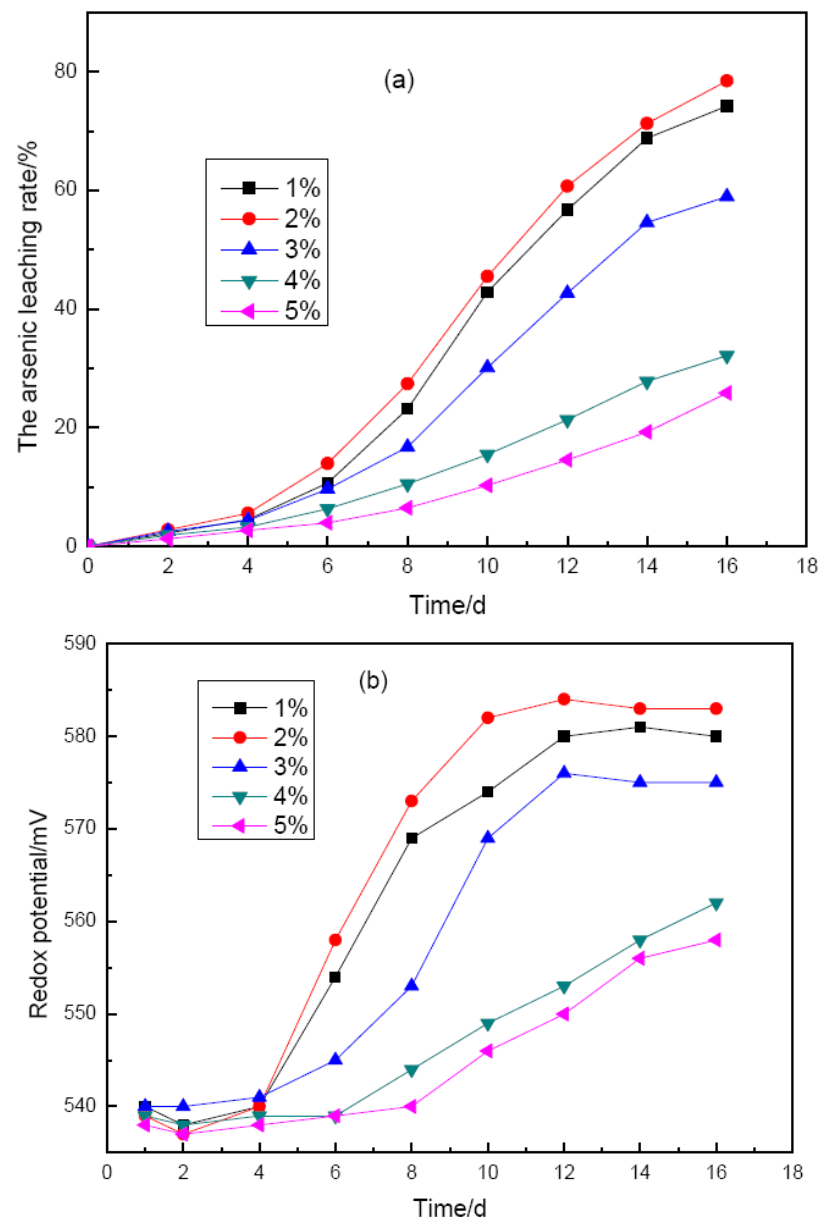

Fig. 2. Effect of pulp density on the silver- catalyzed bioleaching of arsenopyrite over 16 days: the arsenic leaching rate (a) redox potential; (b) versus time respectively.

\section{Effect of $p H$}

The $\mathrm{pH}$ in the mineral leaching process should not only fit the bacterial growth but also fit the leaching of the mineral. Therefore, the actual optimal $\mathrm{pH}$ for the bioleaching process and the optimal $\mathrm{pH}$ for the bacterial growth are often different. Fig. 3 shows the effect of $\mathrm{pH}$ on arsenopyrite bioleaching when the $\mathrm{Ag}^{+}$concentration was $2 \mathrm{mg} / \mathrm{L}$. As shown in Fig. 3(a), after leaching for 16 days, when the $\mathrm{pH}$ was 1.8 and 2.0, the arsenic leaching rates were $77.59 \%$ and $78.46 \%$, respectively, showing no significant differences. When the $\mathrm{pH}$ was 2.5 , during the early stage of the arsenopyrite bioleaching, the arsenic leaching rate was same to the leaching rates when the $\mathrm{pH}$ was 1.8 and 2.0. However, during the later stage of the bioleaching, the arsenic leaching rate was declined significantly. This is because when the $\mathrm{pH}$ is too high, during the later leaching stage, a lot of jarosite precipitations are generated. The jarosite precipitations cover the mineral surface, impede the reaction proceed, thus to affect the ultimate leaching rate and the leaching speed. After leaching for 16 days, the arsenic leaching rate dropped to $64.73 \%$. When the $\mathrm{pH}$ was 1.6 , the arsenic leaching effect was not desirable either. This is because when the $\mathrm{pH}$ is too low, it is difficult for the bacteria to adapt to this high acid environment.
Observations through a microscope found that when $\mathrm{pH}$ was 1.6, the bacterial density in the solution was substantially lower than those in the other experimental groups. As shown in Fig 3 (b), when pH was 1.6, the ORP was also significantly lower than those in the other experimental groups.
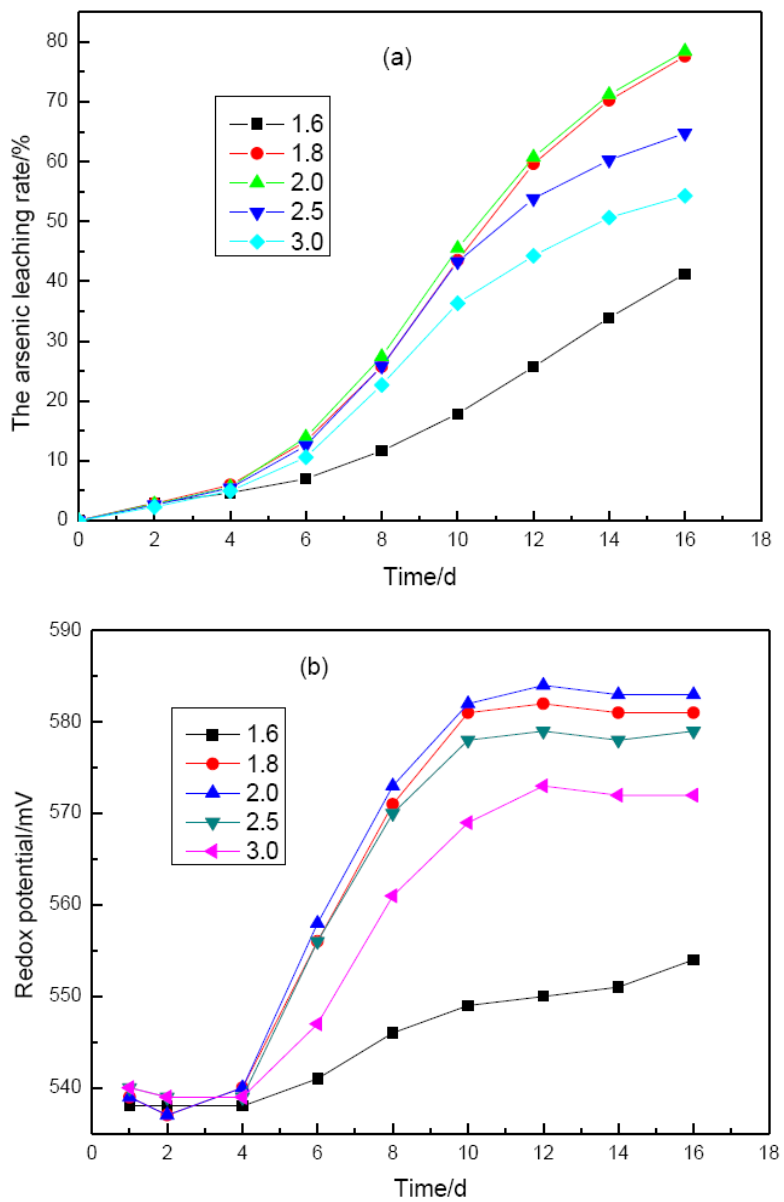

Fig. 3. Effect of $\mathrm{pH}$ on the silver- catalyzed bioleaching of arsenopyrite over 16 days: the arsenic leaching rate (a) redox potential; (b) versus time respectively.

\section{The Effect of Bacteria Inoculation}

Fig. 4 shows the effects of bacteria inoculation on the arsenopyrite bioleaching with and without catalyst. As shown in Fig. 4(a), when the catalyzer was not added, in the bacteria-free leaching system, the value of solution ORP remained relatively low (about 540mV (SCE)) and the arsenic leaching speed was very slow. After bacterial inoculation, with an induction period of 4-5 days, the solution ORP increased gradually with the leaching time. After leaching for 16 day, the OPR value reached $583 \mathrm{mV}$ (SCE); and the arsenic leaching rate was also increased from $4.95 \%$ (bacteria-free leaching) to $55.32 \%$. After adding $2 \mathrm{mg} / \mathrm{L}$ of $\mathrm{Ag}^{+}$, without bacterial inoculation, the arsenic leaching rate (acid leaching) only increased slightly. On the contrary, after bacterial inoculation, the arsenic leaching speed and the ultimate leaching rate were increased significantly. Compared with when the catalyzer was not added, after leaching for 16 days, the arsenic leaching rate increased from $55.32 \%$ to $78.46 \%$. Therefore, with the presence of bacteria, $\mathrm{Ag}^{+}$had a better catalytic effect on the arsenopyrite leaching. As shown in Fig. 4(b), with the $\mathrm{Ag}^{+}$addition, the solution ORP was significant higher with bacterial inoculation than without bacterial inoculation. 

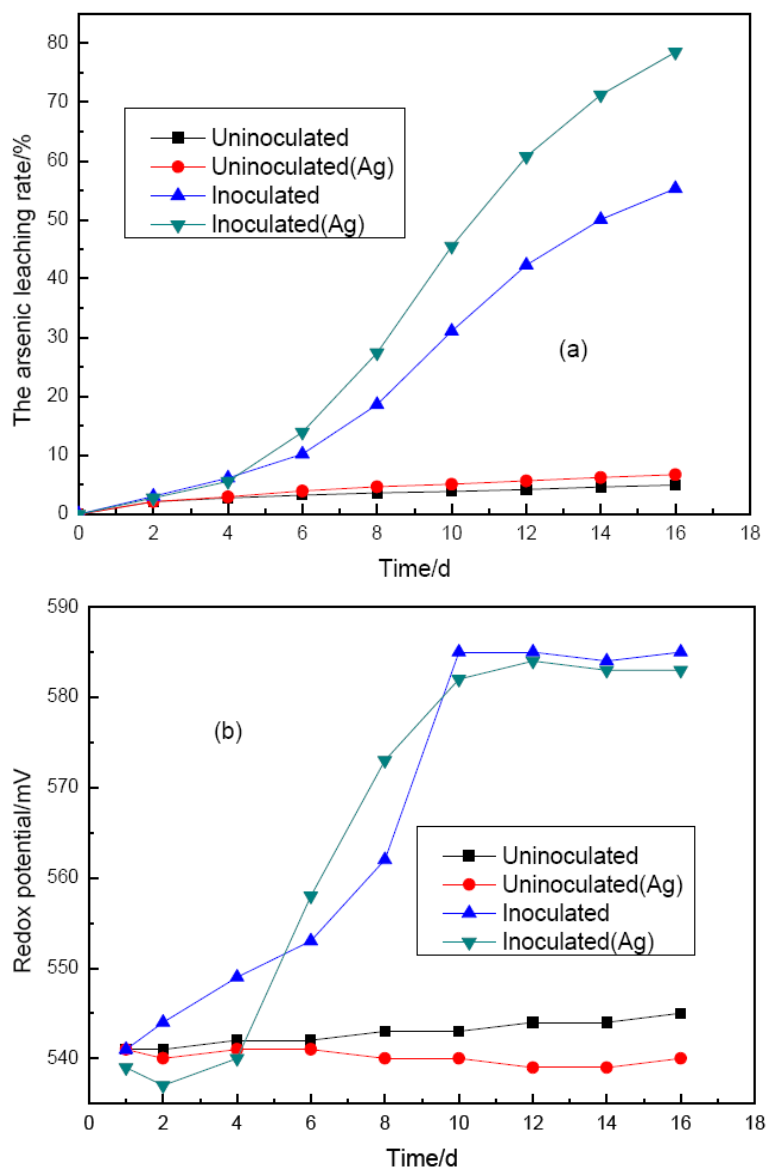

Fig. 4. Effect of inoculation on the non-catalyzed and catalyzed bioleaching of arsenopyrite over 16 days: the arsenic leaching rate (a) redox potential; (b)
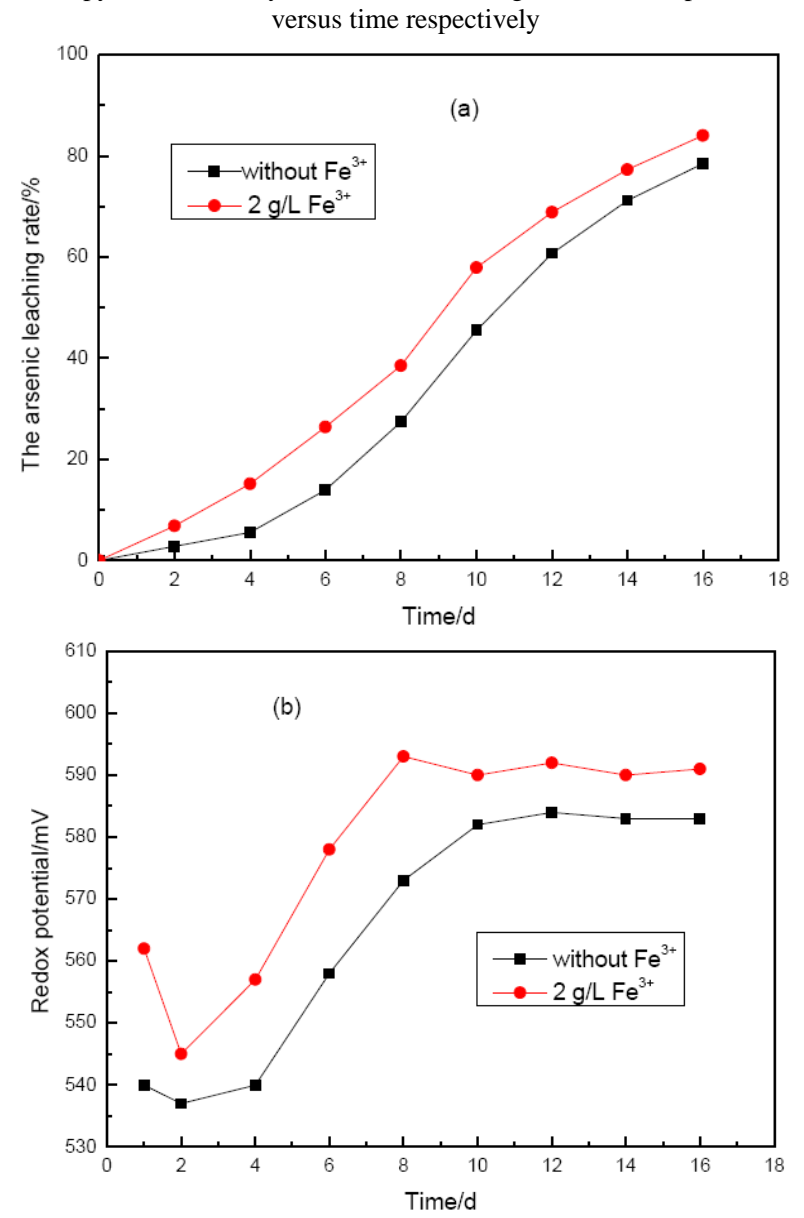

Fig. 5. Effect of ferric ion on the silver- catalyzed bioleaching of arsenopyrite over 16 days: the arsenic leaching rate (a) redox potential; (b) versus time respectively

\section{E. The Effect of $\mathrm{Fe}^{3+}$}

Fig. 5 shows the effect of $\mathrm{Fe}^{3+}$ on arsenopyrite bioleaching when $\mathrm{Ag}^{+}$concentration was $2 \mathrm{mg} / \mathrm{L}$. As shown in Fig. 5(a), adding $\mathrm{Fe}^{3+}$ can speed up the arsenopyrite bioleaching. This is because during the initial stage of leaching, bacteria are in the induction period. In other words, during the initial stage of leaching, the bacterial growth rate is slow; its activity is low; and the concentration of iron ions in solution is also low. Consequently, the arsenic leaching is also slow. After adding $2 \mathrm{~g} / \mathrm{L}$ of $\mathrm{Fe}^{3+}, \mathrm{Fe}^{3+}$ reacts with the mineral and generates $\mathrm{Fe}^{2+}$; $\mathrm{Fe}^{2+}$ provides nutrients for the bacteria; and then the bacteria oxidizes $\mathrm{Fe}^{2+}$ into $\mathrm{Fe}^{3+}$ and regenerates oxidant. The repetition of this process can promote mineral dissolution. The changes of solution ORP are illustrated in Fig. 5(b). As shown in Fig. 5(b), when $\mathrm{Fe}^{3+}$ was not added, only after the leaching system has gone through an induction period of 4 days, can the solution ORP start to rise slowly. By the end of the experiment, the ORP value was $583 \mathrm{mV}$. One the other hand, with the $\mathrm{Fe}^{3+}$ addition, the induction period became significantly shorter; and the solution ORP increased rapidly. By the end of the experiment, ORP value was $591 \mathrm{mV}$. Consequently, the speed of arsenopyrite dissolution was accelerated.

\section{CONCLUSIONS}

$\mathrm{Ag}^{+}$had catalytic effect on arsenopyrite bioleaching. Especially, with the presence of $\mathrm{Fe}^{3+}$, the catalytic effect is even better. When the $\mathrm{Ag}^{+}$concentration was $2 \mathrm{mg} / \mathrm{L}$; the pulp density was $2 \%$; the $\mathrm{pH}$ was 2.0 ; after leaching for 16 days, the arsenic leaching rate was improved about $23.14 \%$ compared with leaching rate when $\mathrm{Ag}^{+}$was not added. However, high concentrations of $\mathrm{Ag}^{+}$would affect the bacterial growth and activity, resulting in a decline of the leaching rate.

\section{ACKNOWLEDGMENT}

This study was financially supported by National Natural Science Foundation of China (No.51104024 and 51374043) and Hunan Provincial Natural Science Foundation of China (No.10JJ6019).

\section{REFERENCES}

[1] J. A. Brierley and C. L. Brierley, "Present and future commercial applications of biohydrometallurgy," Hydrometallurgy,vol. 59, no. 2,pp. 233-239, July 2001.

[2] T. Jiang, Q. Li, Y. Yang, G. Li, and G. Qiu, "Bio-oxidation of arsenopyrite," Trans. Nonferrous Met. Soc. China, vol. 18, no. 6, pp. 1433-1438, June 2008.

[3] R. Cui, H. Yang, G. Zhang, Y. Ma, J. Fan, and K. Li, "Biooxidation of high arsenic gold concentrate with arsenopyrite type," Journal of Chemical Industry and Engineering, vol. 59, no. 12, pp. 3090-3094, December 2008.

[4] Z. Luo, G. Zhang, and Z. Fang, "Bioleaching arsenic-containing gold concentrates with MLY and At.f," The Chinese Journal of Nonferrous Metals, vol. 17, no. 8, pp. 1342-1347, August 2007.

[5] L. Ahonen and O. H. Tuovinen, "Catalytic effects of silver in the micro- biological leaching of finely ground chalcopyrite-containing ore materials in shake flasks," Hydrometallurgy, vol. 24, no. 2, pp. 219-236, February 1990.

[6] C. Zhang, J. Xia, R. Zhang, and G. Qiu, "Comparative study on effects of Tween-80 and sodium isobutyl-xanthate on growth andsulfur-oxidizing activities of Acidithiobacillus albertensis 
BY-05," Transaction of Nonferrous Metals Society of China, vol. 18, no. 4, pp. 1003-1007, April 2008.

[7] W. Zhang and S. Gu, "Catalytic effect of activated carbon on bioleaching of low-grade primary copper sulfide ores," Trans. Nonferrous Met. Soc. China, vol. 17, no. 5, pp. 1123-1127, May 2007.

[8] P. Guo, G. J. Zhang, and J. Y. Cao, "Catalytic Effect of $\mathrm{Ag}^{+}$and $\mathrm{Cu}^{2+}$ on Leaching Realgar $\left(\mathrm{As}_{2} \mathrm{~S}_{3}\right)$," Hydrometallurgy, vol. 106, no. 2,pp. 99-103, February 2011.

[9] Y. Hu, G. Qiu, J. Wang, and D. Wang, "The effect of silver-bearing catalysts on bioleaching of Chalaco- pyrite," Hydrometallurgy, vol. 64 no. 2, pp. 81-88, February 2002.

[10] J. A. Muñoz, D. B. Dreisinger, W. C. Cooper, and S. K. Young, "Silver catalyzed bioleaching of low-grade copper ores. Part III: Column reactors," Hydrometallurgy, vol. 88, no. 1-4, pp. 31-51, January 2007.

[11] J. A. Muñoz, D. B. Dreisinger, W. C. Cooper, and S. K. Young, "Silver catalyzed bioleaching of low-grade copper ores. Part I: Shake flasks tests," Hydrometallurgy, vol. 88, no. 1-4, pp. 1-4, January 2007.

[12] J. A. Muñoz, D. B. Dreisinger, W. C. Cooper, and S. K. Young, "Silver catalyzed bioleaching of low-grade copper ores. Part II: Stirred tank tests," Hydrometallurgy, vol. 88, no. 1-4, pp. 19-34, January 2007.
[13] J. D. Miller and H. Q. Pirtillo, Proceedings of the $13^{\text {th }}$ International Mineral Processing Congress, Warszawa, pp. 851-898, June 1981.

[14] M. Wang, Y. Zhang, T. Deng, and K. Wang, "Kinetic modeling for the bacterial leaching of chalcopyrite catalyzed by silver ions," Miner. Eng, vol. 17, no. 7/8, pp. 943-947, July 2004.

[15] M. Zhang, Q. Yang, G. Zhang, and C. Yang, "Effect of $\mathrm{Ag}^{+}$on bioleaching of arsenic-bearing gold concent-rate," The Chinese Journal of Process Engineering, vol. 12, no. 5, pp. 781-784, May 2012.

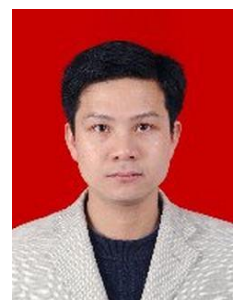

Fang Fang was born in February 1979, Hunan, China. He earned his master degree in chemical engineering in 2005 from Xiangtan university in china. He is working at College of Chemistry and Biological Engineering in Changsha University of Science and Technology as research and teaching assistant. He is currently studying and researching about microbial metallurgy in his doctoral studies. 